\title{
Modulation of Iris Sphincter and Ciliary Muscles by Urocortin 2
}

\author{
M. TAVARES-SILVA ${ }^{1}$, D. FERREIRA ${ }^{1}$, S. CARDOSO ${ }^{1}$, A. R. RAIMUNDO ${ }^{1}$, \\ J. BARBOSA-BREDA ${ }^{2}$, A. LEITE-MOREIRA ${ }^{1,3}$, A. ROCHA-SOUSA ${ }^{1,2}$ \\ ${ }^{1}$ Department of Surgery and Physiology, Faculty of Medicine, University of Porto, Portugal, \\ ${ }^{2}$ Department of Ophthalmology, Centro Hospitalar São João, Portugal, ${ }^{3}$ Department of \\ Cardiothoracic Surgery, Centro Hospitalar São João, Portugal
}

Received April 9, 2017

Accepted January 12, 2018

On-line March 12, 2018

\section{Summary}

Urocortin 2 (UCN2) is a peptide related to corticotropin-releasing factor, capable of activating CRF-R2. Among its multisystemic effects, it has actions in all 3 muscle subtypes. This study's aim was to determine its potential role in two of the intrinsic eye muscle kinetics. Strips of iris sphincter (rabbit) and ciliary (bovine) muscles were dissected and mounted in isometric forcetransducer systems filled with aerated-solutions. Contraction was elicited using carbachol $\left(10^{-6} \mathrm{M}\right.$ for iris sphincter, $10^{-5} \mathrm{M}$ for ciliary muscle), prior adding to all testing substances. UCN2 induced relaxation in iris sphincter muscle, being the effect maximal at $10^{-7} \mathrm{M}$ concentrations ( $-12.2 \%$ variation vs. control). This effect was abolished with incubation of indomethacin, antisauvagine-30, chelerytrine and SQ22536, but preserved with L-nitro-L-arginine. In carbachol pre-stimulated ciliary muscle, UCN2 $\left(10^{-5} \mathrm{M}\right)$ enhanced contraction (maximal effect of $18.2 \%$ increase vs. control). UCN2 is a new modulator of iris sphincter relaxation, dependent of CRF-R2 activation, synthesis of prostaglandins (COX pathway) and both adenylate cyclase and PKC signaling pathways, but independent of nitric oxide production. Regarding ciliary muscle, UCN2 enhances carbachol-induced contraction, in higher doses.

\section{Key words}

Iris sphincter • Ciliary muscle • Urocortin 2 • CRF-R2

\section{Corresponding author}

A. Rocha-Sousa, Departamento de Cirurgia e Fisiologia, Faculdade de Medicina, Universidade do Porto, Al Prof Hernâni Monteiro, 4200-319 Porto, Portugal. Fax: +351 225513646. E-mail: arsousa@med.up.pt

\section{Introduction}

Urocortins are three paralogs of corticotropinreleasing factor (CRF), named as such because the first urocortin identified, urocortin 1 (UCN1), in 1995, had similarities to urotensin and CRF, regarding structure and bioactivity (Vaughan et al. 1995, Donaldson et al. 1996, Fekete and Zorrilla 2007). There are three isoforms of urocortin: UCN1, urocortin 2 (UCN2, or stresscopinrelated peptide) and urocortin 3 (UCN3, or stresscopin) (Hauger et al. 2003). UCN1 is widely distributed in the central nervous system (CNS). At the periphery, it has been detected in the gastrointestinal tract, placenta, adipose tissue, testis, cardiomyocytes, thymus, spleen and kidney (Florio et al. 2004, Boorse and Denver 2006). However, both UCN2 and UCN3 are scarcely expressed in CNS. UCN2 is also expressed in the heart, skeletal muscle, myometrium, adrenal gland, peripheral blood cells and skin. UCN3 expression is considerably lower than that of UCN2 (Boorse and Denver 2006).

CRF related peptides act mainly through two receptors: CRF-R1 and CRF-R2. Both receptors have seven transmembrane domains and belong to the $\mathrm{G}$ protein-coupled receptors family. In most cells, these receptors are coupled to a $G$ or Gs protein, increasing intracellular cyclic adenosine monophosphate (cAMP) levels through the stimulation of adenylate cyclase (Boorse and Denver 2006). The two receptors show significant differences between their pharmacological profile and tissue distribution. Thus, CRF has higher affinity for CRF-R1 receptor, whereas UCN1 binds equally to CRF-R1 and CRF-R2. Both UCN2 and UCN3 
are selective agonists of CRF-R2 receptor (Hauger et al. 2003). Although UCN3 is more selective for CRF-R2, UCN2 exhibits higher potency (Fekete and Zorrilla 2007). The CRF-R1 receptor is primarily expressed in the CNS (Hauger et al. 2003, Boorse and Denver 2006), while CRF-R2 is widely expressed in the peripheral tissues (Florio et al. 2004, Boorse and Denver 2006).

UCN2 is a 38 -aa peptide (Reyes et al. 2001) and its human gene is located at p21.3-4 of chromosome 3 (Hsu and Hsueh 2001). UCN2 seems to play an important role in all three, skeletal, cardiac and smooth muscles. In the former, activation of the CRF-R2 by UCN2 increases contractile force and muscle mass, preventing the loss of skeletal muscle mass (Hinkle et al. 2003, Hinkle et al. 2004); it also allows skeletal muscle to contract and relax faster (Reutenauer-Patte et al. 2012).

Regarding smooth muscle modulation, in human pregnant and nonpregnant myometrial cells, not only UCN2 and CRF-R2 receptor were found, but also UCN2-treatment induced phosphorylation of myosin light chain, which is associated with smooth muscle contraction (Karteris et al. 2004). In the lung, CRF-R2 activation promotes bronchorelaxation (Moffatt et al. 2006). In the gastrointestinal tract, CRF-R2 blockade prevents CRF and UCN1 inhibition of both gastric emptying and ileal muscle contractions (Porcher et al. 2005).

Concerning the cardiovascular system, UCN2 has positive inotropic and lusitropic effects. It also increases coronary blood flow and myocardial function and exerts potent and consistent relaxation of pulmonary and systemic vessels, reducing the arterial blood pressure (Adao et al. 2015).

In the ocular globe, UCN1, UCN2 and UCN3, CRF-R1 and CRF-R2 are expressed in the retinal pigmented epithelium (Hauger et al. 2003, Zmijewski et al. 2007). At the anterior segment of the eye CRF-positive inflammatory cells were detected infiltrating the iris and ciliary body epithelia under experimental autoimmune uveoretinitis in rats (Mastorakos et al. 1995). Additionally, CRF is capable of inducing relaxation of the iris sphincter muscle in toads, which can be blocked using its antagonist (Carr and Zozzaro 2004).

Regarding its effects in the eye, UCN2 seems to be able to protect retinal degeneration following bilateral common carotid artery occlusion, reducing the damage on retinal layers and increasing the thickness of all layers by $40 \%$ and the number of ganglion cells by $50 \%$, in the dose of $40 \mu \mathrm{M}$ (Szabadfi et al. 2009). Also, UCN2 treatment protects the retina from monosodiumglutamate-induced retinal degeneration (Szabadfi et al. 2014). Finally, both UCN1 and UCN2 have a vasodilator effect in the retinal circulation (Kaneko et al. 2007). In this study, UCN2 was used because of its selective effect on CRF-R2.

As the effect of UCN2 in the neurohumoral regulation of the anterior segment of the eye has not been described yet, our purpose is to investigate its role in both rabbit iris sphincter and bovine ciliary muscle kinetics, and the probable subcellular pathways involved.

\section{Methods}

All animal procedures were performed in accordance with the ARVO statement for the Use of Animals in Ophthalmic and Vision Research.

\section{Functional studies}

Specimens preparation - iris

The study was performed in isolated iris sphincter muscles $(\mathrm{n}=44)$ from male New Zealand white rabbits (Oryctolagus cuniculus; 2.0-3.0 kg). Animals were euthanized with a lethal injection of sodium pentobarbital salt $(50 \mathrm{mg} / \mathrm{kg})$ into the marginal ear vein. The eyes were immediately enucleated and placed in a modified Krebs-Ringer (KR) solution at $36{ }^{\circ} \mathrm{C}$, with the following composition in $\mathrm{mM}: \mathrm{NaCl} 98 ; \mathrm{KCl} 4.7$; $\mathrm{MgSO}_{4} .7 \mathrm{H}_{2} \mathrm{O}$ 2.4; $\mathrm{KH}_{2} \mathrm{PO}_{4} 1.2$; glucose $4.5 ; \mathrm{CaCl}_{2} .2 \mathrm{H}_{2} \mathrm{O}$ 2.5; $\mathrm{NaHCO}_{3} 17 ; \mathrm{C}_{3} \mathrm{H}_{3} \mathrm{NaO}_{3} 15$ and $\mathrm{CH}_{3} \mathrm{COONa}$ 5. Once the cornea was removed, the iris sphincter muscles were quickly excised and immersed in the KR solution. After dissecting $5 \times 1 \mathrm{~mm}$ strips of iris sphincter muscle, its ends were tied with silk thread for mounting in a $5 \mathrm{ml}$ horizontal organ bath containing the above-described solution, connecting to an electromagnetic length-tension transducer (University of Antwerp, Belgium), which continuously recorded the force variation. All the surgical procedures were performed under microscope (Zeiss, Stemi 2000C, Germany). Solutions were bubbled with a gas mixture containing $95 \% \mathrm{O}_{2}$ and $5 \% \mathrm{CO}_{2}$ and $\mathrm{pH}$ was maintained between 7.38-7.42.

Iris sphincter muscles were allowed to extend at a constant preload $(0.5 \mathrm{mN})$ and bathing solutions were continuously replaced until muscle length stabilization. They were then switched to isometric conditions and the protocols initiated when muscle tension remained stable during a minimum of $10 \mathrm{~min}$. 
Effects of urocortin 2 in pre-contracted iris sphincter muscle

Once stabilized, rabbit iris sphincter muscles were contracted by adding carbachol $\left(10^{-6} \mathrm{M}\right)$ to the organ bath and stabilization would occur in about $10 \mathrm{~min}$. Increasing doses of UCN2 $\left(10^{-10}-10^{-6} \mathrm{M} ; \mathrm{n}=6\right)$ were added to the organ bath in order to build up a concentration-response curve. The same procedure was recorded with the same UCN2 doses in the presence of: (i) a NO synthase inhibitor, L-nitro-L-arginine $\left(10^{-5} \mathrm{M}\right.$, $\mathrm{n}=9$ ); (ii) a cyclooxygenase (COX) inhibitor, indomethacin $\left(10^{-5} \mathrm{M}, \mathrm{n}=8\right)$; (iii) a CRF-R2 selective antagonist, antisauvagine-30 $\left(10^{-6} \mathrm{M}, \mathrm{n}=7\right)$; (iv) a protein kinase $\mathrm{C}$ (PKC) inhibitor, chelerythrine $\left(10^{-5} \mathrm{M}, \mathrm{n}=6\right)$ and (v) an adenylate cyclase inhibitor, SQ22536 $\left(10^{-6} \mathrm{M}\right.$, $\mathrm{n}=8)$.

In each muscle, two carbachol-induced contractions were studied. One of them was randomly selected to test the effects of UCN2, while the other was used as control (a similar volume of vehicle solution was added to the bath).

\section{Specimens preparation - ciliary muscle}

Bovine globes were collected from the local slaughterhouse and transported to the laboratory within one hour in a container filled with ice. Briefly, one globe was circumferentially cut $5 \mathrm{~mm}$ posterior to the iridocorneal angle. The lens was carefully removed and the anterior compartment was cut in half. Under the microscope, the ciliary body was dissected under cold PSS solution (composition in $\mathrm{mM}$ : $\mathrm{NaCl} \mathrm{118;} \mathrm{KCl} 4.7$; $\mathrm{KH}_{2} \mathrm{PO}_{4}$ 1.2; glucose 11; $\mathrm{CaCl}_{2} .2 \mathrm{H}_{2} \mathrm{O}$ 2.5; $\mathrm{MgCl}_{2} .6 \mathrm{H}_{2} \mathrm{O}$ $\left.1.2 ; \mathrm{NaHCO}_{3} 25\right)$, continuously aerated with the gas mixture mentioned above. Finally, four contiguous $2 \mathrm{~mm}$ strips of ciliary muscle were isolated and two tight 6/0 silk thread knots were tied $2.5 \mathrm{~mm}$ apart - one at the most centrifugal end and the other in the scleral spur residues.

The four muscle strips were horizontally mounted in a four-chamber isometric-force transducer system (DMT, Tissue Bath System 720MO, Denmark). Each chamber was filled with $5 \mathrm{ml}$ of continuouslyaerated PSS solution $\left(\mathrm{T}=36{ }^{\circ} \mathrm{C}, \mathrm{pH}=7.40-7.45\right)$. The strips were slowly stretched, stabilizing at $1 \mathrm{mN}$ passive force, while several PSS washes were done. After $20 \mathrm{~min}$, the baths were filled with a potassium-rich PSS solution (KPSS) to elicit a 3-minute contraction in order to test viability and enhance contractility, followed by PSS wash and another KPSS-PSS cycle. The muscles were then stabilized for $1 \mathrm{~h}$, with PSS substitution every $15 \mathrm{~min}$.

\section{Effects of urocortin 2 in ciliary muscle}

Carbachol $\left(10^{-5} \mathrm{M}\right)$ was added and only the muscle-strips which duplicated their force were studied. Each chamber was randomly assigned to test UCN2 or water (control), $n=10$ pairs. After contractility stabilization, increasing doses of UCN2 $\left(10^{-10}-10^{-5} \mathrm{M}\right)$ or same volume water were subsequently added every 5 min. After the last dose, nothing was added for one hour, after which sodium nitroprusside $\left(10^{-4} \mathrm{M}\right)$ was added to the chambers which tested UCN2, in order to verify viability and relaxation capability.

To test if UCN2 had a precontractility effect, we subjected the muscle strips to a second carbachol-induced contraction: all the chambers were washed with PSS solution several times and the muscles were again subjected to $1 \mathrm{mN}$ passive force. Randomly, two chambers (one of each previous group) were assigned to test $10^{-6} \mathrm{M}$ UCN2 (vs. water), $20 \mathrm{~min}$ prior to the second contraction ( $n=7$ pairs). The active force of both peak and $10 \mathrm{~min}$ after were compared to the prior contraction. Also, the effects of UCN2 $\left(10^{-6} \mathrm{M}\right)$ on resting muscle were analyzed ( $\mathrm{n}=7$ pairs).

\section{Materials}

Most chemicals were obtained from Sigma Chemical Co (St Louis, MO, USA). UCN2 was purchased from Bachem (Bubendorf, Switzerland). The peptides were prepared in aliquots and stored at $-20^{\circ} \mathrm{C}$ for 3 months.

\section{Statistical analysis}

Data are presented as mean $\pm \mathrm{SEM}$. Concentration-response curves of UCN2 in carbachol pre-contracted muscles in each experimental condition were evaluated with two-way repeated measures ANOVA. $p<0.05$ was accepted as significant. The software used was GraphPad Prism $6^{\circledR}$.

\section{Results}

\section{Relaxing effects of UCN2 in iris sphincter muscle}

Active force developed after carbachol-induced contractions of rabbit's iris sphincter muscle-samples was similar between active and control contractions.

Figure 1 shows concentration-response curves obtained after adding UCN2 to pre-contracted rabbit iris sphincter muscles. When compared to control, UCN2 
induced a significant decrease of active force at $10^{-7} \mathrm{M}$ and $10^{-6} \mathrm{M}$ concentrations, being the effect maximal at $10^{-7} \mathrm{M}(-12.2 \pm 2.6 \%$ vs. control).

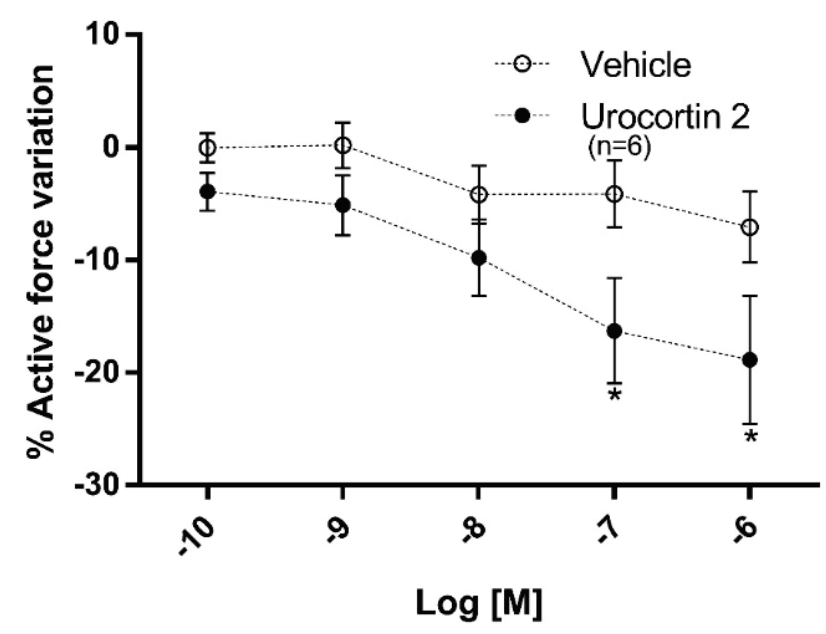

Fig. 1. Concentration-response curves of urocortin 2 $\left(10^{-10}-10^{-6} \mathrm{M}\right)$ in carbachol pre-contracted rabbit iris sphincter muscles, compared with vehicle alone. $p<0.05: *$ vs. control.
Subcellular pathways studies

In order to test the probable subcellular pathways involved in UCN2-mediated relaxation of iris sphincter muscle, several inhibitors of specific mediators were added to the bath $10 \mathrm{~min}$ after carbachol-contraction and $5 \mathrm{~min}$ before UCN2. Neither of these altered per se the active force prior to UCN2 addition.

Influence of NO synthase and COX pathways were tested using L-nitro-L-arginine and indomethacin, respectively. With the former, the UCN2-relaxing effect was preserved, reaching statistical significance at $10^{-9}-10^{-6} \mathrm{M}$ (Fig. 2a). However, UCN2-effect was blunted by indomethacin - there were no statistically significant differences when compared to vehicle solution (Fig. 2b).

Influence of the CRF-R2 receptor was ascertained with antisauvagine-30. This treatment canceled UCN2-relaxing effect (Fig. 2c).

Influence of protein kinase $\mathrm{C}$ and adenylate cyclase signaling pathways were determined using their specific inhibitors: chelerythrine and SQ22536, respectively. Both incubations completely inhibited UCN2-relaxation (Figs $2 \mathrm{~d}$ and 2e), respectively.
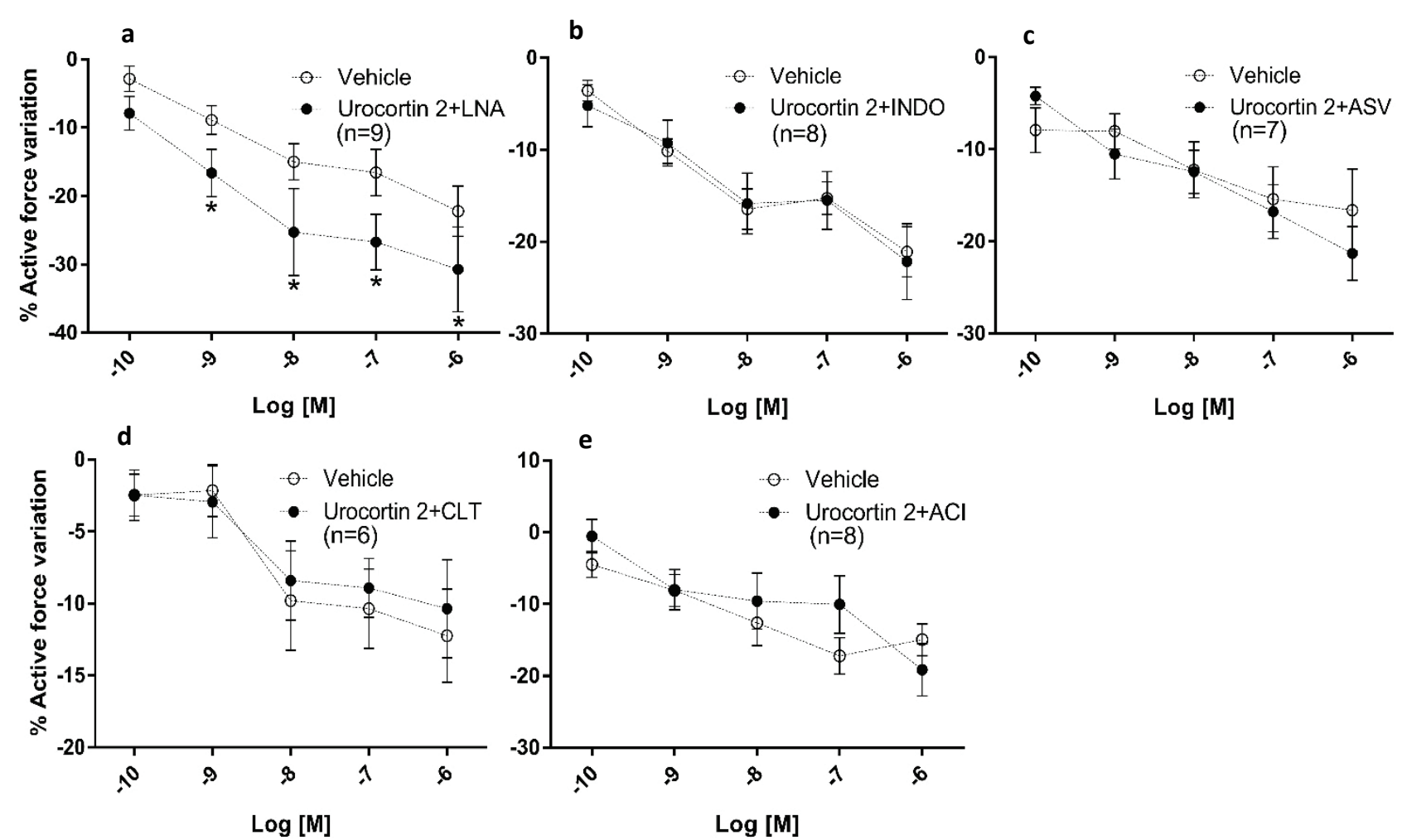

Fig. 2. Concentration-response curves of urocortin $2\left(10^{-10}-10^{-6} \mathrm{M}\right)$ in carbachol pre-contracted rabbit iris sphincter muscles, in the presence of either: a) L-nitro-L-arginine (LNA, $\left.\left.10^{-5} \mathrm{M}\right) ; \mathrm{b}\right)$ indomethacin (INDO, $10^{-5} \mathrm{M}$ ); c) antisauvagine-30 (ASV, 10-6 $\mathrm{M}$ ); d) chelerythrine $\left(\mathrm{CLT}, 10^{-5} \mathrm{M}\right)$; e) SQ22536 (ACI, 10-6 M). Comparison with treatment with vehicle alone. $p<0.05: *$ vs. control. 


\section{Effects of UCN2 in ciliary muscle}

Active force developed after carbachol-induced contractions of bovine ciliary muscles was similar between active and control groups.

Figure 3 shows concentration-response curves obtained after addition of UCN2 $\left(10^{-10}-10^{-5} \mathrm{M}\right)$ to precontracted bovine ciliary muscle. Figure 4 explores the time-dependent effects of UCN2 upon the maximum concentration used $\left(10^{-5} \mathrm{M}\right)$ during $1 \mathrm{~h}$. Only the last dose led to a statistically significant lower fall of the active force, vs. control. Thus, UCN2 $\left(10^{-5} \mathrm{M}\right)$ raised the active force by $18.6 \%$ (after $5 \mathrm{~min}$ ), $16.1 \%$ (after $10 \mathrm{~min}$ ), $18.0 \%$ (after $30 \mathrm{~min}$ ) and $15.5 \%$ (after $1 \mathrm{~h}$ ).

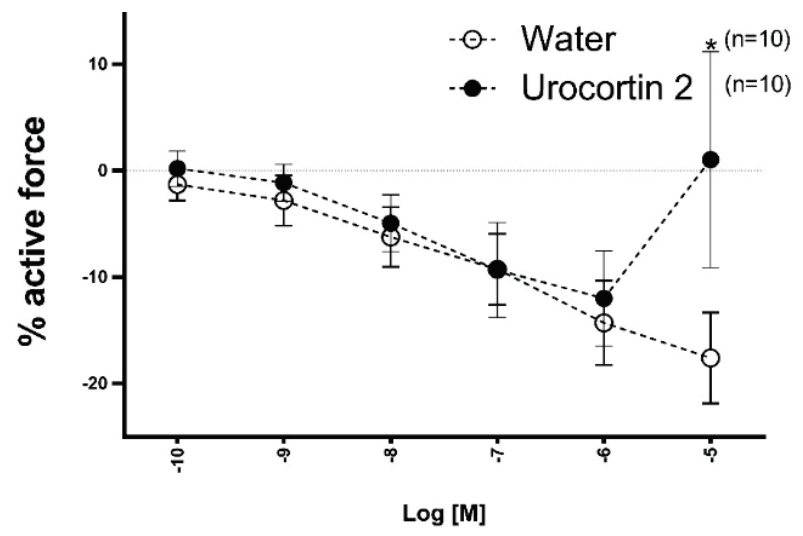

Fig. 3. Concentration-response curves of urocortin 2 $\left(10^{-10}-10^{-5} \mathrm{M}\right)$ in carbachol pre-contracted bovine ciliary muscles, compared with water alone. $p<0.05: *$ vs. control.

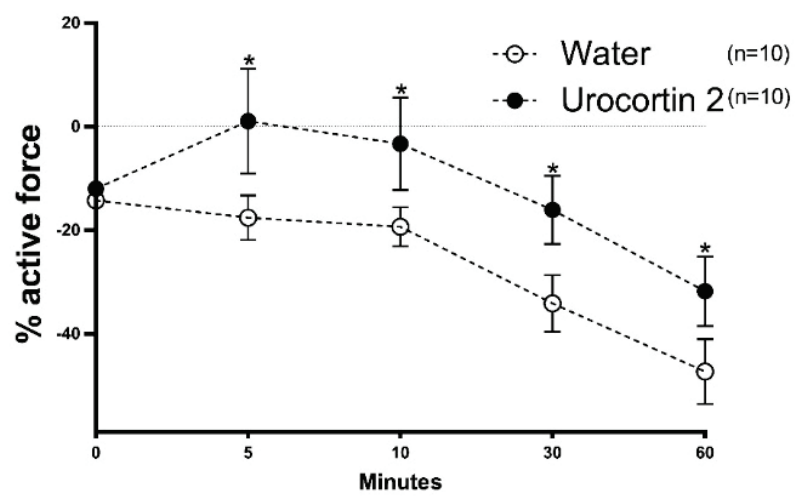

Fig. 4. Response curve of urocortin 2 upon adding the final dose $\left(10^{-5} \mathrm{M}\right)$, measured for $1 \mathrm{~h} . p<0.05$ : * vs. control.

Additionally, UCN2 had no effects on ciliary muscle's resting force, compared to control.

Regarding the pre-contraction studies, there were no statistically significant differences on the second carbachol-elicited contraction between the group treated with UCN2 $10^{-6} \mathrm{M}$ and its control, when compared to the first carbachol-elicited contraction (Fig. 5).

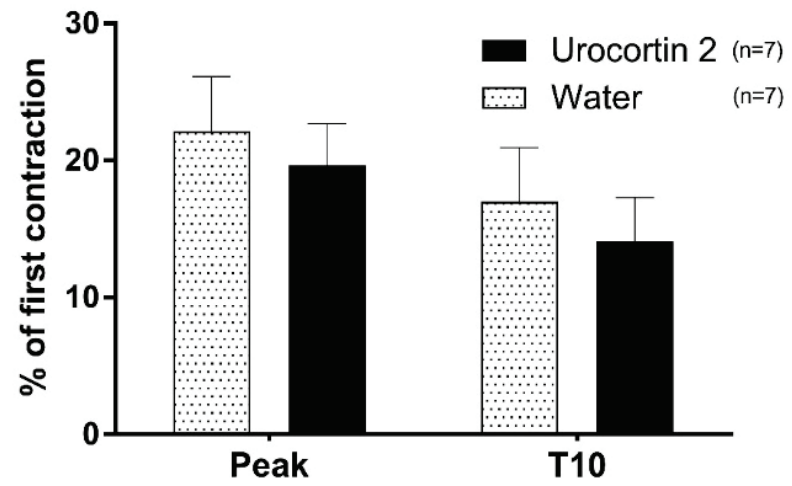

Fig. 5. Comparison of the magnitude of the second carbacholinduced contraction (related to the first contraction) between the $20 \mathrm{~min}$ pre-treatment with urocortin 2 or water. Both peak contraction and $10 \mathrm{~min}$ after were analyzed. No differences reached significance.

\section{Discussion}

This study describes UCN2 as a new neurohumoral factor that modulates relaxation of iris sphincter muscle. This effect is dependent on CRF-R2 activation, as well as the synthesis of prostaglandins (COX pathway), adenylate cyclase and PKC signaling pathways. It is independent of nitric oxide production. Therefore, this relaxation is mainly a postsynaptic effect.

The addition of UCN2 to carbachol pre-contracted iris sphincter muscles promoted a significant decrease in force for the highest concentrations of UCN2 $\left(10^{-7}-10^{-6} \mathrm{M}\right)$, being maximal using UCN2 at $10^{-7} \mathrm{M}$, which is clearly physiological. Because the iris sphincter muscle is a circular muscle and small variations of its radius determine relevant changes in strength, this force variation can lead to a significant change in pupil diameter and tonicity.

Searching new agents capable of modulating iris muscles' tone (in this case, iris sphincter) is relevant. The search for new options for intraoperative mydriasis, without significant systemic side effects, (such as those characteristic of phenylephrine or acetylcholine antagonists) is very important. One of the most common ocular surgeries, the cataract surgery, requires maintenance of mydriasis, which is critical to the safety and surgical ease of the procedure (Grob et al. 2014).

Many substances have shown to be effective in inducing relaxation of this muscle. Following the same protocol, the selective stimulation of $\mathrm{ET}_{\mathrm{B} 2}$ receptors produced similar results, either in magnitude or in dosing (Rocha-Sousa et al. 2009). Additionally, ghrelin promoted a more exuberant relaxation of rabbit's iris sphincter muscle $\left(34.1 \pm 12.1 \%\right.$ at $\left.10^{-5} \mathrm{M}\right)$ (Rocha-Sousa 
et al. 2006). Other molecules involved in iris sphincter relaxation are beta-adrenergic receptors agonists, with an important role played by $\beta_{2^{-}}$and $\beta_{3}$-receptors (Topalkara et al. 2006). These effects are potentiated by pre-treatment with muscarinic blockers, such as atropine and ipratropium bromide (Barilan et al. 2003). Moreover, serotonin - possibly through $5-\mathrm{HT}_{1 \mathrm{~A}}$ receptors (Barnett and Osborne 1993) - phosphodiesterase inhibitors (PDEI) (type 1 to 5, which emphasizes the role of cAMP and cGMP pathways) (Yogo et al. 2009), adrenomodulin (Uchikawa et al. 2005), sodium nitroprusside and c-type natriuretic peptide (Ding and Abdel-Latif 1997) and okadaic acid (Wang et al. 1994) treatment can also lead to iris sphincter relaxation.

Regarding subcellular pathways, cAMP and PKA pathways were also involved in relaxation of rat's coronary arteries and guinea pig smooth muscle of the gastric antrum, positive inotropic and lusitropic effects in ventricular myocytes, and possibly bronchorelaxation in mice, through activation of CRF-R2 (Petkova-Kirova et al. 2000, Moffatt et al. 2006, Smani et al. 2007, Adao et al. 2015). On the other hand, PKC pathway was responsible for UCN2 effects observed in human pregnant myometrium and rat ventricular myocytes (Karteris et al. 2004, Smani et al. 2010).

The effects of UCN2 in rabbit's iris sphincter muscle were not replicated in bovine ciliary muscle. A similar scenario happens with ghrelin: although it is capable of inducing relaxation of pre-contracted samples of rabbit's iris sphincter and dilator muscles, and rat's iris sphincter muscle (Rocha-Sousa et al. 2006), it is not able to do so in bovine ciliary muscle (unpublished data by our group). The dose-response curve was similar to control from $10^{-10} \mathrm{M}$ to $10^{-6} \mathrm{M}$. Interestingly, administration of UCN2 $\left(10^{-5} \mathrm{M}\right)$ was capable of rising carbachol-contracted ciliary muscle force relative to control, being the effect maximal 5 min later (18.6\% higher), but statistically significant throughout the whole period studied $(1 \mathrm{~h})$. Two possible explanations arise for this pattern of response: 1) only a higher dose was sufficient to produce a measurable effect, through CRF-R2, which may be repressed, downregulated or competitively antagonized by an endogenous substance, or 2) perhaps UCN2 in higher doses loses specificity for CRF-R2 and interferes with other local receptors or systems. However, it should be noted that, in another study, the effects of retinal degeneration protection following bilateral common carotid artery occlusion were achieved using a $4 \times 10^{-5} \mathrm{M}$ concentration of UCN2
(Szabadfi et al. 2009), which was higher than the maximum dose used in this study.

Finally, UCN2 $\left(10^{-6} \mathrm{M}\right)$ incubated prior to a second carbachol-induced contraction was incapable of changing the magnitude of the second contraction and it did not alter the force generated by resting ciliary muscle.

In fact, not all studies report a relaxation effect provided by UCN2. A good example is its cardiovascular effects, where it exerts positive inotropic effects in isolated ventricular myocytes (maximal at $10^{-7} \mathrm{M}$ ) (Yang et al. 2006). Moreover, in human myometrial cells, UCN2 is able to induce phosphorylation of myosin light chain (which is involved in the initiation of smooth muscle contraction), being the effect maximal with $\mathrm{UCN} 2$ at $10^{-7} \mathrm{M}$ after $5 \mathrm{~min}$ of treatment and returning to basal levels after $45 \mathrm{~min}$ (Karteris et al. 2004). Finally, in the skeletal muscle, activation of CRF-R2 by UCN2 increases contractile force and muscle mass (Hinkle et al. 2003, Hinkle et al. 2004).

Studying possible molecules that modulate ciliary muscle tension is of crucial importance, given its modulation of aqueous humor outflow. Ciliary muscle contraction increases the outflow of aqueous humor through the conventional route, via its attachment to the scleral spur, widening the functional spaces of the trabecular meshwork (Wiederholt et al. 2000), but it also lowers the outflow facility through the unconventional one; the converse occurs with its relaxation (Rasmussen and Kaufman 2014, Johnson et al. 2017). It seems that ciliary muscle and myofibroblast-like cells of the trabecular outflow system act as functional antagonists while modulating outflow resistance, being the resistance of this route lowered through contraction of the former and relaxation of the latter (Tamm et al. 2015). In fact, eliciting ciliary muscle contraction is the basis of the pharmacologically-induced reduction of intraocular pressure through cholinergic drugs (Akaishi et al. 2009, Overby et al. 2014, Braunger et al. 2015), which is one of the aqueous humor drainage mechanisms that supports the glaucoma pharmacotherapy.

So far, many components have been studied regarding their ability to induce contraction of ciliary muscle samples. These include muscarinic agonists, mainly $\mathrm{M}_{3}$ subtype (acting through phospholipase $\mathrm{C}$ activity and intracellular calcium accumulation, in a $\mathrm{G}_{\mathrm{q} / 11}$-coupled pathway) (Yasui et al. 2008); $\mathrm{CB}_{1}$-agonist, anandamide, which induces contraction (dependent on phospholipase $C$ and $\beta \gamma$ subunit of $G_{i} / G_{o}$ proteins), alone or synergistically with carbachol 
(Lograno and Romano 2004, Romano and Lograno 2013); endothelin-1, through $\mathrm{ET}_{\mathrm{A}}$ receptor activation (though, in low-doses, it elicits relaxation, via $\mathrm{ET}_{\mathrm{B}}$ receptors) (Kamikawatoko et al. 1995); serotonin, through 5- $\mathrm{HT}_{2}$ and 5- $\mathrm{HT}_{3}$ receptors (Lograno and Romano 2003) and histamine, via $\mathrm{H}_{1}$ receptors, which activates phospholipase $\mathrm{C}$ and increases intracellular calcium (Markwardt et al. 1997). Moreover, ciliary muscle contraction can be provoked through membranebound PKC stimulation (using phorbol 12-myristate 13-acetate) (Thieme et al. 1999) or inhibition of PKC, using staurosporin or $\mathrm{H} 7$, causing potentiation of carbachol contraction (Lograno et al. 1991, Daniele et al. 1997); PDEI (N-ethylmaleimide and iodoacetic acid) (Yoshino and Suzuki 1992); epidermal growth factorurogastrone (EGF) (Wiederholt et al. 1998); substance $P$ (Lograno and Daniele 1988) and 4-aminopyridine, a potassium channel blocking drug, which appears to potentiate the evoked ciliary muscle contractions without changing resting tension (Zacharias and Guerrero 1985). Finally, platelet-activating factor, iloprost, $\mathrm{PGI}_{2}, \mathrm{PGE}_{2}$, $\mathrm{PGE}_{1}$, latanoprost, travoprost, $\mathrm{PGF}_{2 \alpha}$, 17-phenyl-PGF $2 \alpha$ and bitamoprost, a prostamide derivate - using both $\mathrm{CB}_{1}$ and FP receptors - have all been implied in raising ciliary muscle tension (Lograno et al. 1992, Krauss et al. 1997, Yoshitomi et al. 2002, Romano and Lograno 2007).

As far as the neurohumoral regulation of the eye's anterior segment is concerned, a new potential modulator of intra-ocular muscles kinetics has been described - UCN2 stimulation represents a new mechanism of relaxation of the iris sphincter muscle and seems to raise the tension of carbachol-contracted ciliary muscle.

\section{Conflict of Interest}

There is no conflict of interest.

\section{Acknowledgements}

Supported by grants from the Portuguese Foundation for Science and Technology (Nr. PTDC/SAU-ORG/110683/ 2009) and from NORTE2020 (NORTE-01-0246-FEDER000007) through Cardiovascular R\&D Unit (FCT Nr. 51/94) and support of University Porto/Santander Totta IJUP 2009/Banco Santander (Nr. 129).

\section{References}

ADAO R, SANTOS-RIBEIRO D, RADEMAKER MT, LEITE-MOREIRA AF, BRAS-SILVA C: Urocortin 2 in cardiovascular health and disease. Drug Discov Today 20: 906-914, 2015.

AKAISHI T, ODANI-KAWABATA N, ISHIDA N, NAKAMURA M: Ocular hypotensive effects of anti-glaucoma agents in mice. J Ocul Pharmacol Ther 25: 401-408, 2009.

BARILAN A, NACHMAN-RUBINSTEIN R, ORON Y, GEYER O: Muscarinic blockers potentiate beta-adrenergic relaxation of bovine iris sphincter. Graefes Arch Clin Exp Ophthalmol 241: 226-231, 2003.

BARNETT NL, OSBORNE NN: The effect of serotonin on the rabbit isolated iris sphincter muscle. Curr Eye Res 12 : 665-673, 1993.

BOORSE GC, DENVER RJ: Widespread tissue distribution and diverse functions of corticotropin-releasing factor and related peptides. Gen Comp Endocrinol 146: 9-18, 2006.

BRAUNGER BM, FUCHSHOFER R, TAMM ER: The aqueous humor outflow pathways in glaucoma: A unifying concept of disease mechanisms and causative treatment. Eur J Pharm Biopharm 95: 173-181, 2015.

CARR JA, ZOZZARO PE: The toad iris assay: a simple method for evaluating CRH action on the sympathetic nervous system. Gen Comp Endocrinol 135: 134-141, 2004.

DANIELE E, VILLANI G, LOGRANO MD: Effects of phorbol ester on carbachol-induced contraction in bovine ciliary muscle: possible involvement of protein kinase C. Eur J Pharmacol 330: 247-256, 1997.

DING KH, ABDEL-LATIF AA: Actions of C-type natriuretic peptide and sodium nitroprusside on carbacholstimulated inositol phosphate formation and contraction in ciliary and iris sphincter smooth muscles. Invest Ophthalmol Vis Sci 38: 2629-2638, 1997.

DONALDSON CJ, SUTTON SW, PERRIN MH, CORRIGAN AZ, LEWIS KA, RIVIER JE, VAUGHAN JM, VALE WW: Cloning and characterization of human urocortin. Endocrinology 137: 2167-2170, 1996.

FEKETE EM, ZORRILLA EP: Physiology, pharmacology, and therapeutic relevance of urocortins in mammals: ancient CRF paralogs. Front Neuroendocrinol 28: 1-27, 2007.

FLORIO P, VALE W, PETRAGLIA F: Urocortins in human reproduction. Peptides 25: 1751-1757, 2004. 
GROB SR, GONZALEZ-GONZALEZ LA, DALY MK: Management of mydriasis and pain in cataract and intraocular lens surgery: review of current medications and future directions. Clin Ophthalmol 8: 1281-1289, 2014.

HAUGER RL, GRIGORIADIS DE, DALLMAN MF, PLOTSKY PM, VALE WW, DAUTZENBERG FM: International Union of Pharmacology. XXXVI. Current status of the nomenclature for receptors for corticotropin-releasing factor and their ligands. Pharmacol Rev 55: 21-26, 2003.

HINKLE RT, DONNELLY E, CODY DB, BAUER MB, ISFORT RJ: Urocortin II treatment reduces skeletal muscle mass and function loss during atrophy and increases nonatrophying skeletal muscle mass and function. Endocrinology 144: 4939-4946, 2003.

HINKLE RT, DONNELLY E, CODY DB, BAUER MB, SHELDON RJ, ISFORT RJ: Corticotropin releasing factor 2 receptor agonists reduce the denervation-induced loss of rat skeletal muscle mass and force and increase non-atrophying skeletal muscle mass and force. J Muscle Res Cell Motil 25: 539-547, 2004.

HSU SY, HSUEH AJ: Human stresscopin and stresscopin-related peptide are selective ligands for the type 2 corticotropin-releasing hormone receptor. Nat Med 7: 605-611, 2001.

JOHNSON M, MCLAREN JW, OVERBY DR: Unconventional aqueous humor outflow: A review. Exp Eye Res 158: 94-111, 2017.

KAMIKAWATOKO S, TOKORO T, AZUMA H, HAMASAKI H, ISHIDA A: The effects of endothelin-1 on isolated bovine ciliary muscles. Exp Eye Res 61: 559-564, 1995.

KANEKO Y, SAITO M, MORI A, SAKAMOTO K, KAMETAKA S, NAKAHARA T, ISHII K: Vasodilation of retinal arteriole mediated by corticotropin-releasing factor receptor is impaired in streptozotocin-induced diabetic rats. Biol Pharm Bull 30: 985-989, 2007.

KARTERIS E, HILLHOUSE EW, GRAMMATOPOULOS D: Urocortin II is expressed in human pregnant myometrial cells and regulates myosin light chain phosphorylation: potential role of the type-2 corticotropin-releasing hormone receptor in the control of myometrial contractility. Endocrinology 145: 890-900, 2004.

KRAUSS AH, WIEDERHOLT M, STURM A, WOODWARD DF: Prostaglandin effects on the contractility of bovine trabecular meshwork and ciliary muscle. Exp Eye Res 64: 447-453, 1997.

LOGRANO MD, DANIELE E: Substance P as a transmitter in the human ciliary muscle. Pharmacol Res Commun 20: 901-905, 1988.

LOGRANO MD, DANIELE E, GIOVANAZZI S, GUARRERA A, NICOSIA S: Effects of prostaglandins and PAF on the contractility of the bovine ciliary muscle. Pharmacol Res 25: 195-202, 1992.

LOGRANO MD, DANIELE E, TRABUCCHI M, GOVONI S: Evidence for protein kinase C modulation of the ciliary muscle response to carbachol and desensitization. Eur J Pharmacol 204: 49-53, 1991.

LOGRANO MD, ROMANO MR: Pharmacological characterization of the 5-HT1A, 5-HT2 and 5-HT3 receptors in the bovine ciliary muscle. Eur J Pharmacol 464: 69-74, 2003.

LOGRANO MD, ROMANO MR: Cannabinoid agonists induce contractile responses through Gi/o-dependent activation of phospholipase $\mathrm{C}$ in the bovine ciliary muscle. Eur J Pharmacol 494: 55-62, 2004.

MARKWARDT KL, MAGNINO PE, PANG IH: Histamine induced contraction of human ciliary muscle cells. Exp Eye Res 64: 713-717, 1997.

MASTORAKOS G, BOUZAS EA, SILVER PB, SARTANI G, FRIEDMAN TC, CHAN CC, CASPI RR, CHROUSOS GP: Immune corticotropin-releasing hormone is present in the eyes of and promotes experimental autoimmune uveoretinitis in rodents. Endocrinology 136: 4650-4658, 1995.

MOFFATT JD, LEVER R, PAGE CP: Activation of corticotropin-releasing factor receptor-2 causes bronchorelaxation and inhibits pulmonary inflammation in mice. FASEB J 20: 1877-1879, 2006.

OVERBY DR, BERTRAND J, SCHICHT M, PAULSEN F, STAMER WD, LUTJEN-DRECOLL E: The structure of the trabecular meshwork, its connections to the ciliary muscle, and the effect of pilocarpine on outflow facility in mice. Invest Ophthalmol Vis Sci 55: 3727-3736, 2014.

PETKOVA-KIROVA PS, GAGOV HS, DURIDANOVA DB: Urocortin hyperpolarizes stomach smooth muscle via activation of Ca2+-sensitive K+ currents. J Muscle Res Cell Motil 21: 639-645, 2000.

PORCHER C, JUHEM A, PEINNEQUIN A, SINNIGER V, BONAZ B: Expression and effects of metabotropic CRF1 and CRF2 receptors in rat small intestine. Am J Physiol Gastrointest Liver Physiol 288: G1091-G1103, 2005. 
RASMUSSEN CA, KAUFMAN PL: The trabecular meshwork in normal eyes and in exfoliation glaucoma. J Glaucoma 23: S15-S19, 2014.

REUTENAUER-PATTE J, BOITTIN FX, PATTHEY-VUADENS O, RUEGG UT, DORCHIES OM: Urocortins improve dystrophic skeletal muscle structure and function through both PKA- and Epac-dependent pathways. Am J Pathol 180: 749-762, 2012.

REYES TM, LEWIS K, PERRIN MH, KUNITAKE KS, VAUGHAN J, ARIAS CA, HOGENESCH JB, GULYAS J, RIVIER J, VALE WW, SAWCHENKO PE: Urocortin II: a member of the corticotropin-releasing factor (CRF) neuropeptide family that is selectively bound by type 2 CRF receptors. Proc Natl Acad Sci U S A 98: 2843-2848, 2001.

ROCHA-SOUSA A, SARAIVA J, AMARAL M, ALVES-FARIA P, FALCAO-REIS F, LEITE-MOREIRA AF: ETB2 receptor subtype stimulation relaxes the iris sphincter muscle. Physiol Res 58: 835-842, 2009.

ROCHA-SOUSA A, SARAIVA J, HENRIQUES-COELHO T, FALCAO-REIS F, CORREIA-PINTO J, LEITEMOREIRA AF: Ghrelin as a novel locally produced relaxing peptide of the iris sphincter and dilator muscles. Exp Eye Res 83: 1179-1187, 2006.

ROMANO MR, LOGRANO MD: Evidence for the involvement of cannabinoid CB1 receptors in the bimatoprostinduced contractions on the human isolated ciliary muscle. Invest Ophthalmol Vis Sci 48: 3677-3682, 2007.

ROMANO MR, LOGRANO MD: Signaling cross-talk between cannabinoid and muscarinic systems actives Rho-kinase and increases the contractile responses of the bovine ciliary muscle. Eur J Pharmacol 702: 174-179, 2013.

SMANI T, CALDERON-SANCHEZ E, GOMEZ-HURTADO N, FERNANDEZ-VELASCO M, CACHOFEIRO V, LAHERA V, ORDONEZ A, DELGADO C: Mechanisms underlying the activation of L-type calcium channels by urocortin in rat ventricular myocytes. Cardiovasc Res 87: 459-466, 2010.

SMANI T, DOMINGUEZ-RODRIGUEZ A, HMADCHA A, CALDERON-SANCHEZ E, HORRILLO-LEDESMA A, ORDONEZ A: Role of Ca2+-independent phospholipase A2 and store-operated pathway in urocortin-induced vasodilatation of rat coronary artery. Circ Res 101: 1194-1203, 2007.

SZABADFI K, ATLASZ T, REGLODI D, KISS P, DANYADI B, FEKETE EM, ZORRILLA EP, TAMAS A, SZABO K, GABRIEL R: Urocortin 2 protects against retinal degeneration following bilateral common carotid artery occlusion in the rat. Neurosci Lett 455: 42-45, 2009.

SZABADFI K, KISS P, REGLODI D, FEKETE EM, TAMAS A, DANYADI B, ATLASZ T, GABRIEL R: Urocortin 2 treatment is protective in excitotoxic retinal degeneration. Acta Physiol Hung 101: 67-76, 2014.

TAMM ER, BRAUNGER BM, FUCHSHOFER R: Intraocular pressure and the mechanisms involved in resistance of the aqueous humor flow in the trabecular meshwork outflow pathways. Prog Mol Biol Transl Sci 134: 301-314, 2015.

THIEME H, NASS JU, NUSKOVSKI M, BECHRAKIS NE, STUMPFF F, STRAUSS O, WIEDERHOLT M: The effects of protein kinase $\mathrm{C}$ on trabecular meshwork and ciliary muscle contractility. Invest Ophthalmol Vis Sci 40: 3254-3261, 1999.

TOPALKARA A, KARADAS B, TOKER MI, KAYA T, DURMUS N, TURGUT B: Relaxant effects of betaadrenoceptor agonist formoterol and BRL 37344 on bovine iris sphincter and ciliary muscle. Eur J Pharmacol 548: 144-149, 2006.

UCHIKAWA Y, OKANO M, SAWADA A, ASADA Y, KOBAYASHI H, WADA A, NAO-I N, OHKURA M, TANAKA N, YAMAMOTO R: Relaxant effect of adrenomedullin on bovine isolated iris sphincter muscle under resting conditions. Clin Exp Pharmacol Physiol 32: 675-680, 2005.

VAUGHAN J, DONALDSON C, BITTENCOURT J, PERRIN MH, LEWIS K, SUTTON S, CHAN R, TURNBULL AV, LOVEJOY D, RIVIER C, RIVIER J, SAWCHENKO PE, VALE W: Urocortin, a mammalian neuropeptide related to fish urotensin I and to corticotropin-releasing factor. Nature 378: 287-292, 1995.

WANG XL, AKHTAR RA, ABDEL-LATIF AA: Studies on the properties of myo-inositol-1,4,5-trisphosphate 5-phosphatase and myo-inositol monophosphatase in bovine iris sphincter smooth muscle: effects of okadaic acid and protein phosphorylation. Biochim Biophys Acta 1222: 27-36, 1994.

WIEDERHOLT M, GROTH J, STRAUSS O: Role of protein tyrosine kinase on regulation of trabecular meshwork and ciliary muscle contractility. Invest Ophthalmol Vis Sci 39: 1012-1020, 1998. 
WIEDERHOLT M, THIEME H, STUMPFF F: The regulation of trabecular meshwork and ciliary muscle contractility. Prog Retin Eye Res 19: 271-295, 2000.

YANG LZ, KOCKSKAMPER J, HEINZEL FR, HAUBER M, WALTHER S, SPIESS J, PIESKE B: Urocortin II enhances contractility in rabbit ventricular myocytes via $\mathrm{CRF}(2)$ receptor-mediated stimulation of protein kinase A. Cardiovasc Res 69: 402-411, 2006.

YASUI F, MIYAZU M, YOSHIDA A, NARUSE K, TAKAI A: Examination of signalling pathways involved in muscarinic responses in bovine ciliary muscle using YM-254890, an inhibitor of the Gq/11 protein. Br J Pharmacol 154: 890-900, 2008.

YOGO T, KANEDA T, NEZU Y, HARADA Y, HARA Y, TAGAWA M, URAKAWA N, SHIMIZU K: Effects of various selective phosphodiesterase inhibitors on relaxation and cyclic nucleotide contents in porcine iris sphincter. J Vet Med Sci 71: 1449-1453, 2009.

YOSHINO H, SUZUKI R: Effect of phosphodiesterase inhibitors on bovine ciliary muscle and outflow facility. $J$ Ocul Pharmacol 8: 99-105, 1992.

YOSHITOMI T, YAMAJI K, ISHIKAWA H, OHNISHI Y: Effect of latanoprost, prostaglandin F(2)alpha and nipradilol on isolated bovine ciliary muscle. Jpn J Ophthalmol 46: 401-405, 2002.

ZACHARIAS J, GUERRERO S: Effects of cholinergic drugs and 4-aminopyridine on cat ciliary muscle contractility. Invest Ophthalmol Vis Sci 26: 1309-1313, 1985.

ZMIJEWSKI MA, SHARMA RK, SLOMINSKI AT: Expression of molecular equivalent of hypothalamic-pituitaryadrenal axis in adult retinal pigment epithelium. J Endocrinol 193: 157-169, 2007. 